\title{
Calf health from birth to weaning - an update
}

\author{
Ingrid Lorenz
}

\begin{abstract}
Research on calf health and welfare has intensified in the past decades. This is an update on a review series on calf health from birth to weaning published ten years ago.

Good colostrum management is still recognised as the single most important factor to preventing calf morbidity and mortality, however, it is now known that immunoglobulins are only one of many components of colostrum that are vital for the calf's development. Other non-nutrient factors like leucocytes, hormones and growth factors, oligosaccharides as well as microRNAs have significant effects on the development and maturation of the intestinal and systemic immune functions. They also promote the maturation and function of the intestine, thus enabling the calf to digest and absorb the nutrients provided with colostrum and milk. The improved energetic status of colostrum-fed neonates is reflected by an accelerated maturation of the somatotropic axis, which stimulates body growth and organ development. Colostrum oligosaccharides are presumed to play a major role in the development of a healthy intestinal flora.

A biologically normal (intensive) milk-feeding programme is subsequently necessary for optimal body growth, organ development and resistance to infectious diseases. Ad-libitum or close to ad-libitum feeding in the first three to four weeks of life also leaves calves less hungry thus improving calf welfare. Only calves fed intensively with colostrum and milk are able to reach their full potential for performance throughout their life.

Public interest in farm animal welfare is growing in past decades, which makes it necessary to have a closer look at contentious management practices in the dairy industry like early separation of the dairy calf from the dam with subsequent individual housing. Public objection to these practices cannot be mitigated through educational efforts. Contrary to common opinion there is no evidence that early cow-calf separation is beneficial for the health of calf or cow. There is evidence of behavioural and developmental harm associated with individual housing in dairy calves, social housing improves feed intake and weight gains, and health risks associated with grouping can be mitigated with appropriate management.

In conclusion, there are still many management practices commonly applied, especially in the dairy industry, which are detrimental to health and welfare of calves.
\end{abstract}

Keywords: Calf health, Calf welfare, Disease prevention, Colostrum management, Dairy calf nutrition, Cow-calf separation, Calf housing

(c) The Author(s). 2021 Open Access This article is licensed under a Creative Commons Attribution 4.0 International License, which permits use, sharing, adaptation, distribution and reproduction in any medium or format, as long as you give appropriate credit to the original author(s) and the source, provide a link to the Creative Commons licence, and indicate if changes were made. The images or other third party material in this article are included in the article's Creative Commons licence, unless indicated otherwise in a credit line to the material. If material is not included in the article's Creative Commons licence and your intended use is not permitted by statutory regulation or exceeds the permitted use, you will need to obtain permission directly from the copyright holder. To view a copy of this licence, visit http://creativecommons.org/licenses/by/4.0/. The Creative Commons Public Domain Dedication waiver (http://creativecommons.org/publicdomain/zero/1.0/) applies to the data made available in this article, unless otherwise stated in a credit line to the data. 


\section{Introduction}

Calfhood diseases have a major impact on the economic viability of cattle operations, due to the direct costs of calf losses and treatment and the long term effects on performance [1]. After calf health was prioritised as one of the most important animal health issues facing the Irish livestock industry in an expert Policy Delphi study conducted on behalf of Animal Health Ireland (AHI) [2] in 2010, all aspects of calf health from birth to weaning have been reviewed [3-5] as a scientific basis for providing evidence-based information on successful calf rearing to Irish Farmers. An update of these reviews was made necessary by a multitude of new scientific findings, especially in the area of colostrum management, further feeding of the dairy calf and other calf welfare related topics. This article considers the most important scientific evidence since 2011 that either substantiates or changes our understanding of calf health from birth to weaning.

\section{Colostrum management}

Good colostrum management is widely recognised as the single most important factor to preventing calf morbidity and mortality [6]. Traditionally most of the positive effects of colostrum are attributed to the high content of immunoglobulins (Ig). Calves are indeed born without protective immunoglobulins (Ig) due to the structure of the bovine placenta and therefore depend on the successful passive transfer of maternal Ig from colostrum [7]. However, colostrum provides a variety of other important ingredients. In the past years the knowledge about the biological significance of these ingredients increased considerably.

\section{Important non-nutrient factors in colostrum}

Bovine colostrum contains high concentrations of viable maternal leucocytes similar to those in peripheral blood, but with relatively more macrophages/monocytes and fewer lymphocytes [8]. Maganck et al. [9] identified the lymphocytes mainly as T-lymphocytes. The uptake of colostral leucocytes through the intestinal barrier is possible with the preferential route of uptake being through follicle-associated epithelium of Peyer's patches [8]. Viable maternal leucocytes are destroyed by freezing [10] and significantly reduced by heat treatment [11]. Studies comparing the effects of cell-free (through lysis of cells by flash-freezing in liquid nitrogen) vs. whole colostrum in calves found significant differences in number and composition of blood monocytes [12] and lower numbers of $\mathrm{B}$ - and $\mathrm{T}$ - cells at some timepoints after vaccination in calves receiving cell-free colostrum [13]. However, the effect of maternal leucocytes on common calfhood diseases has so far been found to be small, with only one out of three studies finding a significantly higher chance of antibiotic treatment and a higher frequency of fever in calves that received cell-free colostrum $[12,14,15]$.

Bovine colostrum contains bioactive proteins in higher abundance then mature milk. When the proteomes of colostrum and milk are categorized according to their biological function, the largest difference is observed in the category of proteins responsible for metabolic processes [16]. In particular, colostrum contains a large number of growth factors, including insulin-like growth factors (IGFs) and insulin in high concentrations [17]. These substances mainly exert their effects locally, since receptors for IGF-I, IGF-II and insulin can be found throughout the intestines in newborn calves, however, absorption is negligible [18]. While IGF-I alone does not influence development of the intestinal epithelium in an experimental setting, an extract of first-milked bovine colostrum increased villus circumferences and heights in small intestine, as well as epithelial cell proliferation rate in the intestines. The mechanism responsible for this observation is not clear [19]. Feeding of colostrum as opposed to formula with comparable nutrient content stimulates mucosal growth and increases the absorptive capacity in the small intestines [20, 21]. Increased nutrient and glucose absorption thus allows increased glucose supply and hepatic glycogen storage, which improves the glucose status. The improved energetic status of colostrum-fed neonates is reflected by an accelerated maturation of the somatotropic axis, leading especially to enhanced production of IGF-I in the neonate and thus promoting anabolic processes. [22].

Another substance group present in bovine colostrum in high concentrations are oligosaccharides [23], whose effects are not yet completely understood. However, they are very likely to prevent pathogen adhesion to the intestinal epithelium [24], may enhance the uptake of IgG [25], and serve as carbon sources for beneficial bacteria to promote their growth and establishment in the intestine [26].

Colostrum also contains high amounts of microRNAs. MicroRNAs are short, non-coding RNA molecules that can regulate gene expression at the post-transcriptional level and which are believed to provide a method of signalling from the mother to the neonate. They can reach the intestines and be absorbed into the bloodstream since they are sheltered from digestion in extracellular vesicles. MicroRNAs may play an important role in the development of the intestinal epithelium, as well as the maturation of the calves immune system [27].

\section{Extended feeding of colostrum}

Extended feeding of colostrum or a mixture of colostrum and milk for three days not only increases Ig concentration in the serum [28], but also promotes small 
intestinal growth and maturation [29]. Feeding transition milk decreases the incidence of calves suffering from disease [30]. In conclusion, it can be assumed that bioactive substances from colostrum other than Ig highly effect intestinal health in the neonatal calf through enhancing gut maturation and immunity [18].

\section{Testing of colostrum quality}

However, passive transfer of Ig from the dam to the calf via colostrum still plays the major role in providing immediate systemic immunity after the calf is born. Colostrum quality is defined by Ig concentration and remains one crucial factor for successful passive transfer. Since direct laboratory methods for the determination of Ig in colostrum are elaborate and expensive, the use of cow-side testing of colostrum quality has been intensively investigated. Buczinski and Vandeweerd [31] conducted a systematic review and meta- analysis on the diagnostic accuracy of Brix refractometry for the assessment of bovine colostrum quality. Evaluation of 11 studies representing 4,251 colostrum samples showed that a cut-point of $22 \%$ Brix can be used to diagnose good quality colostrum (IgG $\geq 50 \mathrm{~g} / \mathrm{L})$ with a post-test probability of $94.3 \%$ (90.7-96.9\%), whereas the posttest probability of good colostrum with a Brix value $<18 \%$ was only $22.7 \%$ (12.3-39.2\%). The authors suggest using the two cut-points to select good quality colostrum (sample with Brix $\geq 22 \%$ ) or to discard poor quality colostrum (sample with Brix $<18 \%$ ). When sample results are between these two values, supplementation with higher quality colostrum should be considered.

\section{Monitoring of passive immunity status}

For many decades an individual calf threshold of $10 \mathrm{~g} / \mathrm{L}$ of serum Ig has been used to define failure of passive transfer of immunity. A serum protein concentration of $52 \mathrm{~g} / \mathrm{L}$ was found to be equivalent to $10 \mathrm{~g} / \mathrm{L}$ serum IgG and was suggested as test threshold for healthy calves up to an age of 8 days [32]. Recent studies challenged this simplistic approach to the monitoring of passive immunity status. Windeyer et al. [33] found a decreased risk for respiratory disease in calves with serum total protein values $\geq 57 \mathrm{~g} / \mathrm{L}$, Chigerwe et al. [34] considered serum total protein levels between 58 and $63 \mathrm{~g} / \mathrm{L}$ as optimum for indicating adequate passive transfer of immunity in dairy calves. The USDA National Animal Health Monitoring System's Dairy Study 2014 [35] showed, that the risk for calf morbidity and mortality decreased significantly with increased serum Ig concentrations. In light of these findings, a panel of calf specialists revised the standards for passive immunity transfer for the US dairy industry according to latest scientific evidence [36]. The proposed standard includes 4 serum IgG categories: excellent, good, fair, and poor with serum IgG levels of $\geq 25.0,18.0-24.9,10.0-17.9$, and $<10 \mathrm{~g} / \mathrm{L}$, respectively. Table 1 shows the corresponding total protein and Brix \% levels, as well as suggested achievable standards for the four categories on a herd level.

\section{Hygienic quality of colostrum}

Bacterial contamination of colostrum occurs frequently on many dairies, with two associated concerns; a risk of transfer of infection and decreased absorption of IgG in the intestines. Total bacterial count should not exceed $100,000 \mathrm{cfu} / \mathrm{mL}$, and faecal coliforms should be below $10,000 \mathrm{cfu} / \mathrm{mL}$ [37]. Heat treatment of colostrum without reducing IgG levels and changing viscosity is possible at $60{ }^{\circ} \mathrm{C}$ for $60 \mathrm{~min}$ [38]. However, even though IgG levels remain stable and the bacterial count can be largely reduced, heat treatment of colostrum also reduces the content of somatic cells, IgA, insulin, IGF-I, as well as other proteins, which could result in biologically important effects on the developing immune system of the neonate fed heat-treated colostrum [11].

\section{Further nutrition and weaning of the dairy calf}

For most of the last century research in the area of calf nutrition and management focused on reducing the amounts of whole milk fed to dairy calves prior to weaning by all means possible [39]. This led to the traditional recommendation to feed dairy calves milk or milk replacer to an amount of approximately $10 \%$ of the their body weight (BW) per day [40]. This concept of "restricted feeding" was introduced to encourage calves to eat concentrates as early as possible and thus to minimise costs for relatively expensive liquid feeds. However, starter concentrate intake is negligible in the first 3 weeks of life, irrespective of the amount of milk fed [41,

Table 1 Consensus serum lgG concentrations and equivalent total protein (TP) and Brix measurements, and percentage of calves recommended in each transfer of passive immunity category (adapted from Lombard et al. [36])

\begin{tabular}{lllll}
\hline $\begin{array}{l}\text { Passive transfer of } \\
\text { immunity category }\end{array}$ & $\begin{array}{l}\text { Serum IgG } \\
\text { category } \mathbf{( g / L )}\end{array}$ & $\begin{array}{l}\text { Equivalent serum } \\
\text { total protein }(\mathbf{g} / \mathbf{L})\end{array}$ & $\begin{array}{l}\text { Equivalent } \\
\text { serum Brix \% }\end{array}$ & $\begin{array}{l}\text { Recommended percentage } \\
\text { of calves on farm in category }\end{array}$ \\
\hline Excellent & $\geq 25.0$ & $\geq 62$ & $\geq 9.4$ & $>40$ \\
Good & $18.0-24.9$ & $58-61$ & $8.9-9.3$ & $\sim 30$ \\
Fair & $10.0-17.9$ & $51-57$ & $8.1-8.8$ & $\sim 20$ \\
Poor & $<10.0$ & $<51$ & $<8.1$ & $<10$ \\
\hline
\end{tabular}


42]. After the first 3 weeks of life, starter concentrate intake increases which allows for compensatory growth [40]. This feeding regime only allows for maintenance requirements and minimal weight gain in early calfhood under thermo-neutral and otherwise favourable conditions [43]. It has been known for a long time that calves can grow a lot faster if they are supplied with more nutrients $[44,45]$. However, worldwide interest in early calf nutrition has only been increasing since the beginning of the current century. Diaz et al. [46] showed in a study published 2001 that the recommendations for nutrient requirements of the young calf were inadequate at the time. By feeding three different levels of milk replacer with high protein content they also demonstrated that calves on a higher plain of nutrition did not only gain weight faster, but also showed higher feed efficiency. Protein deposition increased linearly with feeding rate, whereas fat deposition increased less from the middle to highest feeding rate, indicating that on higher plains of nutrition a high protein content of the milk replacer supports lean tissue growth. Furthermore, early studies demonstrated that calves suckling their dam or otherwise fed ad libitum ingest about $20 \%$ of body weight (BW) per day in milk and can reach more than one $\mathrm{kg}$ of daily weight gain [41, 47]. Feeding milk ad-libitum or close to ad-libitum will delay starter intake, which has to be taken into account for the weaning process [48]. In two seminal studies Kahn et al. [42, 49] presented a method which allows feeding high volumes of milk in the first three to four weeks of live without the drawback of stagnating growth during weaning due to poor starter intake. They compared calves on conventional restricted feeding ( $10 \%$ of body weight) with calves that received close to ad-libitum volumes of milk (20\% of body weight) for 23 and 25 days, respectively. Subsequently milk volumes were gradually reduced to $10 \%$ of body weight over four days (step-down) in calves previously fed close to ad-libitum. Both groups were weaned on day 50. Calves in the step-down group did not only gain weight and grow much faster than conventionally fed calves, they also showed higher starter and forage intake after the reduction of feeding volumes. This also resulted in a higher forestomach weight, ruminal wall thickness and better papillae development [42]. In one study conventionally fed calves showed significantly more days with diarrhoea in the third and fourth week of live than step-down calves [49]. A different approach to avoid growth check during weaning of ad-libitum fed calves is to delay weaning age up to the twelfth week of live [48].

Meanwhile numerous studies identified the effects of biologically normal milk feeding programs (also called intensified or accelerated feeding programs) when compared with conventional restricted feeding. The importance of the feeding intensity on gastrointestinal and systemic development of calves has recently been reviewed [18]. Besides the obvious increased body weight and body growth, enhanced organ growth and development (e.g. rumen, small intestine, mammary gland) as well as stimulation of the endocrine pancreas have been found. Metabolic changes include greater systemic metabolic activity, elevated metabolic activity in the ruminal epithelium and in the omental adipose tissue. Analogous to the effect of colostrum, a high plain of milk feeding is necessary to stimulate the somatotropic axis and to enhance maturation of the intestinal immune system [18].

The influence of early calf nutrition on lifetime performance was first examined by Soberon et al. [50]. Analysing data from two dairy herds they found a significant correlation between preweaning average daily gain (ADG) and milk yield in first lactation. For every $1 \mathrm{~kg}$ of preweaning ADG, heifers in the two herds produced $850 \mathrm{~kg}$ and $1113 \mathrm{~kg}$ more milk during their first lactation, respectively. The authors concluded that early life programming for lifetime performance must commence immediately after birth in form of liquid feed. Soberon and Van Amburgh [51] conducted a meta-analysis of 12 data sets that reported early-life intake and growth rates as well as firstlactation milk production. In that study calves fed more milk or milk replacer in early life were two times more likely to have a greater milk yield in first lactation and for every kilogram of preweaning ADG, first lactation milk yield increased by $1,550 \mathrm{~kg}$. A second meta-analysis concluded that preweaning ADG minimally affects milk production when growth rate is below $0.5 \mathrm{~kg} / \mathrm{d}$, but has a greater influence as growth rate increased from 0.5 to $0.9 \mathrm{~kg} / \mathrm{d}$, indicating that the long term benefits from accelerated growth in calves can only be gained if early calf nutrition allows for close to normal growth rates [52].

Restricted feeding of dairy calves also has animal welfare implications. Calves fed limited amounts of milk show behaviours indicative of chronic hunger. Calves provided $5 \mathrm{~L} /$ $\mathrm{d}$ of milk vocalized at higher rates and with higher pitch calls compared with calves fed $8 \mathrm{~L} / \mathrm{d}$ [53]. If calves are fed by automatic milk feeding systems the number of unrewarded visits (i.e., visits to the feeder when calves are not entitled to receive milk) increases markedly with decreasing milk allowance [54-58]. Calves fed ad-libitum performed on average 2.1 unrewarded visits per day [57], whereas restrictively fed calves entered the feeder up to 35 times per day without being entitled to receive milk [55]. Restricted milk allowance also reduces play behaviour [59], which can also serve as an indicator of animal welfare [60].

\section{Feeding of colostrum and milk containing residues of antimicrobial substances}

Feeding of waste milk (milk unfit for human consumption) potentially containing residues of antimicrobial substances is common practice in the dairy industry 
worldwide [61-65]. In the European Union feeding of milk containing residues of antimicrobials to calves on the farm of origin is not generally prohibited [66]. The exposure of microorganisms to subinhibitory concentrations of antimicrobials is known to select for antimicrobial resistance [67]. Several studies reported the shedding of an increased proportion of antimicrobial-resistant faecal bacteria when calves are fed waste milk containing antimicrobial residues [68-70]. Pereira et al. [71] fed milk experimentally spiked with ceftiofur, penicillin, ampicillin, and oxytetracycline below the minimum inhibitory concentrations and found a significantly greater proportion of E. coli resistant to ampicillin, cefoxitin, ceftiofur, streptomycin and tetracycline when compared to calves fed with antimicrobial-free milk. Also, a greater proportion of $E$. coli isolates from calves fed residue containing milk were resistant to 3 or more antimicrobial drugs when compared to the control group.

The reason for feeding waste milk containing milk under withdrawal from cows treated with antibiotics during lactation is mainly economical in nature [62]. This differs from the feeding of colostrum potentially containing antimicrobial residues due to dry cow treatment (DCT), since the adequate provision of colostrum is of major importance for the survival, health and performance of the calf as detailed previously. A scientific opinion by the European Food Safety Authority (EFSA) Panel on Biological Hazards (BIOHAZ) [66] comes to the conclusion that faecal shedding of antimicrobialresistant bacteria will not increase when calves are fed colostrum from cows undergoing DCT if the interval from the dry-off treatment until calving is as long as or longer than the minimum specified in the Summary of Product Characteristics of the antimicrobial product. However, this finding is based on limited scientific evidence and in one field study on antimicrobial residues in colostrum, one third of the samples showed residues in concentrations above maximum residue limits (MRL), mostly cloxacillin [66]. Another study analysing colostrum samples of 200 cows that underwent DCT for the presence of $\beta$-lactam antimicrobials found residues of cloxacillin in 49 colostrum samples (in 34 samples with concentrations above the MRL) from 88 cows that were treated with cloxacillin- containing products. However, looking into the different commercial products used, the vast majority of positive samples were obtained from cows treated with one formulation providing an extended period of protective antibiotic levels in the udder. Residues of other $\beta$-lactam antimicrobials were rarely found [72].

There are initial reports indicating that feeding waste milk containing antimicrobial residues does not only foster selection of antibiotic resistances but also has an impact on the composition of the intestinal [73-75] and nasal [75] microbiota.

\section{Early separation from the dam and individual housing of the dairy calf}

Under natural conditions, cows separate from the herd before giving birth and subsequently keep their calf away from the herd for some days. After that, calves join the herd to form groups with their peers engaging in social relationships [76].

On the vast majority of commercial dairy farms, however, calves are separated from their dams within hours or at least within very few days after they are born. There are several perceived reasons for this practice by producers, as summarized by Flower and Weary [76]. First of all, there are economic reasons, since calves left with cows to suckle would consume high volumes of saleable milk, whereas handfed calves are often fed on waste milk or less expensive milk replacer. Suckling is thought to interfere with return to oestrus and with milk led-down in cows. Furthermore, handfed calves are easier to monitor for colostrum intake and general health. Finally, there is a compassionate argument that prolonged time to bond between cow and calf would increase separation distress. Veterinarians consider improved calf health to be the main reason to support the early separation of cow and calf [77].

On the other hand, public interest in the welfare of farm animals is rising, increasing the potential for contentious practices to damage the public image of the industry. When asked "Should dairy calves be separated from the cow within the first few hours after birth?" $76 \%$ of those without involvement in the dairy industry objected to the practice [78]. In an online study including German and US citizens, the majority of participants were in favour of keeping cows and calves together for a prolonged period of time [79]. Ventura et al. [80] analysed the effect of an educational visit to a dairy farm on the perceptions concerning farming practices of Canadian citizens with little prior knowledge of dairy farming. Most of the participants were unaware of the practice of early cow-calf separation, but raised concerns about it after the farm tour. A survey among Brazilian participants living in urban environments, with little or no association with dairy production, came to similar results [81]. In general, they were unaware that cows are separated from their calf at birth and most participants did not support this practice independent of provision of additional information.

In light of these findings the available scientific literature on the effect of early cow-calf separation on cow and calf health was systematically reviewed [82]. The authors concluded that the evidence extracted from the included journal articles does not support a recommendation of early dairy cow-calf separation on the basis of calf or cow health. The articles addressing calf diarrhoea pointed to beneficial or no effects of suckling. Mixed results were 
found for cryptosporidiosis, other common pathogenic causes for diarrhoea have not been evaluated in detail. Furthermore, no consistent evidence of increased risk of pneumonia in calves reared with the cow was found. For measures of calf immunity and mortality, no consistent pattern was observed, with studies split between those showing benefits versus risks associated with suckling. However, in studies detailing the risks of leaving the calf with the dam, colostrum intake was not systematically monitored. With respect to cow health, the review indicates that suckling is protective against mastitis and that cow-calf contact is not a significant risk factor for Johne's disease. Early separation (within $24 \mathrm{~h}$ postpartum) was found to reduce acute distress responses of cows and calves in a review on the effects of prolonged cow-calf contact [83]. However, longer cow-calf contact typically had positive longer-term effects on calves, promoting more normal social behaviour, reducing abnormal behaviour, and sometimes reducing responses to stressors. Calf weight gains were increased during the milk-feeding period, when cows were allowed to nurse their calves, without consistent evidence of reduced milk production over a longer period.

Individual housing of dairy calves is another contentious practice very common on dairy farms [84]. European legislation allows calves to be kept individually for the first 8 weeks of life, however, it prohibits solid walls in individual calf pens, so that calves have to be able to have tactile contact to other calves (Council Directive 2008/119/EC). Individual housing of young calves is preferred by many producers, since it is perceived that group housing increases the risk of infectious disease, even though scientific evidence is ambiguous on this issue [5]. However, especially housing calves in larger groups requires more skills and poses more challenges to management [85]. Several studies have looked into the effects of housing calves in pairs under the assumption, that this smallest possible group would enable calves to socialize more naturally while minimising the disadvantages of group housing [8690]. None of these studies found a negative impact on the health of calves housed in pairs. The advantages of pair housing are comparable to those of housing calves in larger groups, as reviewed by Costa et al. [91]. The reviewed studies showed that individually reared calves show deficient social skills, difficulties in coping with novel situations, and poorer learning abilities. Social housing for calves also improves solid feed intakes preweaning and helps improve weight gains before and after calves are weaned from milk to solid feed.

\section{Conclusions}

Enhanced colostrum intake and a subsequent biologically normal (intensive) milk feeding programme support body growth and organ development in dairy calves.
Only providing traditional restricted feeding is detrimental to resistance to disease, life-time performance and leaves calves hungry for long periods of time. This practice is therefore not consistent with animal welfare principles. Other contentious practices in the dairy industry, like early cow-calf separation and subsequent individual housing of the dairy calf, gain increasing attention from the general public. Scientific evidence does not support the common opinion, that these practices are beneficial for the health of calf or cow. Profound changes in current calf management practices are needed to improve dairy calf health and survival, enhance long-time performance of dairy heifers and satisfy consumer interests in farm animal welfare.

\section{Acknowledgements}

Not applicable.

Authors' contributions

The author(s) read and approved the final manuscript.

Funding

Not applicable.

Availability of data and materials

Not applicable.

\section{Declarations}

Ethics approval and consent to participate

Not applicable.

Consent for publication

Not applicable.

\section{Competing interests}

The author declares no competing interests.

Received: 22 December 2020 Accepted: 10 March 2021

Published online: 16 March 2021

References

1. Donovan GA, Dohoo IR, Montgomery DM, Bennett FL. Calf and disease factors affecting growth in female Holstein calves in Florida, USA. Prev Vet Med. 1998;33:1-10.

2. More SJ, McKenzie K, O'Flaherty J, Doherty ML, Cromie AR, Magan MJ. Setting priorities for non-regulatory animal health in Ireland: results from an expert Policy Delphi study and a farmer priority identification survey. Prev Vet Med. 2010:95:198-207.

3. Lorenz I, Mee JF, Early B, More SJ: Calf health from birth to weaning. I. General aspects of disease prevention. 2011.

4. Lorenz I, Fagan J, More SJ. Calf health from birth to weaning. II. Management of diarrhoea in pre-weaned calves. 2011.

5. Lorenz I, Earley B, Fallon R, Gilmore J, Hogan I, Kennedy E, More SJ. Calf health from birth to weaning. III. Disease prevention and management with particular reference to calf pneumonia. 2011.

6. Godden SM, Lombard JE, Woolums AR. Colostrum Management for Dairy Calves. Veterinary Clinics of North America Food Animal Practice. 2019;35: 535-56.

7. Godden S. Colostrum Management for Dairy Calves. Veterinary Clinics of North America: Food Animal Practice. 2008:24:19-39.

8. Liebler-Tenorio EM, Riedel-Caspari G, Pohlenz JF. Uptake of colostral leukocytes in the intestinal tract of newborn calves. Vet Immunol Immunopathol. 2002:85:33-40.

9. Meganck V, Goddeeris BM, Stuyven E, Piepers S, Cox E, Opsomer G. Development of a method for isolating bovine colostrum mononuclear leukocytes for phenotyping and functional studies. Vet J. 2014;200:294-8. 
10. Donovan DC, Reber AJ, Gabbard JD, Aceves-Avila M, Galland KL, Holbert KA, Ely LO, Hurley DJ. Effect of maternal cells transferred with colostrum on cellular responses to pathogen antigens in neonatal calves. Am J Vet Res. 2007:68:778-82.

11. Mann S, Curone G, Chandler TL, Moroni P, Cha J, Bhawal R, Zhang S. Heat treatment of bovine colostrum: I. Effects on bacterial and somatic cell counts, immunoglobulin, insulin, and IGF-I concentrations, as well as the colostrum proteome. J Dairy Sci. 2020;103:9368-83.

12. Langel SN, Wark WA, Garst SN, James RE, McGilliard ML, Petersson-Wolfe CS, Kanevsky-Mullarky I. Effect of feeding whole compared with cell-free colostrum on calf immune status: The neonatal period. J Dairy Sci. 2015;98: 3729-40.

13. Langel SN, Wark WA, Garst SN, James RE, McGilliard ML, Petersson-Wolfe CS, Kanevsky-Mullarky I. Effect of feeding whole compared with cell-free colostrum on calf immune status: Vaccination response. J Dairy Sci. 2016;99: 3979-94.

14. Novo SMF, Costa JFdR, Baccili CC, Sobreira NM, Silva BT, de Oliveira PL, Hurley DJ, Gomes V. Effect of maternal cells transferred with colostrum on the health of neonate calves. Res Vet Sci. 2017;112:97-104.

15. Martin CC, de Oliveira SMFN, dos Reis Costa JF, Baccili CC, Silva BT, Hurley DJ, Gomes V. Influence of feeding fresh colostrum from the dam or frozen colostrum from a pool on indicator gut microbes and the inflammatory response in neonatal calves. Research in Veterinary Science 2020.

16. Nissen A, Andersen PH, Bendixen E, Ingvartsen KL, Røntved CM. Colostrum and milk protein rankings and ratios of importance to neonatal calf health using a proteomics approach. J Dairy Sci. 2017;100:2711-28.

17. Blum JW. Nutritional physiology of neonatal calves. Journal of Animal Physiology Animal Nutrition. 2006;90:1-11.

18. Hammon HM, Liermann W, Frieten D, Koch C. Review: Importance of colostrum supply and milk feeding intensity on gastrointestinal and systemic development in calves. Animal. 2020;14:133-43.

19. Roffler B, Fäh A, Sauter SN, Hammon HM, Gallmann P, Brem G, Blum JW Intestinal Morphology, Epithelial Cell Proliferation, and Absorptive Capacity in Neonatal Calves Fed Milk-Born Insulin-Like Growth Factor-I or a Colostrum Extract1. J Dairy Sci. 2003;86:1797-806.

20. Steinhoff-Wagner J, Görs S, Junghans P, Bruckmaier RM, Kanitz E, Metges CC, Hammon HM. Intestinal Glucose Absorption but Not Endogenous Glucose Production Differs between Colostrum- and Formula-Fed Neonatal Calves. The Journal of Nutrition. 2010;141:48-55.

21. Steinhoff-Wagner J, Zitnan R, Schönhusen U, Pfannkuche H, Hudakova M, Metges CC, Hammon HM. Diet effects on glucose absorption in the small intestine of neonatal calves: Importance of intestinal mucosal growth, lactase activity, and glucose transporters. J Dairy Sci. 2014;97:6358-69.

22. Hammon HM, Steinhoff-Wagner J, Schönhusen U, Metges CC, Blum JW. Energy metabolism in the newborn farm animal with emphasis on the calf: endocrine changes and responses to milk-born and systemic hormones. Domest Anim Endocrinol. 2012;43:171-85

23. Fischer-Tlustos AJ, Hertogs K, van Niekerk JK, Nagorske M, Haines DM, Steele MA. Oligosaccharide concentrations in colostrum, transition milk, and mature milk of primi- and multiparous Holstein cows during the first week of lactation. J Dairy Sci. 2020;103:3683-95.

24. Martín M-J, Martín-Sosa S, Hueso P. Binding of milk oligosaccharides by several enterotoxigenic Escherichia coli strains isolated from calves. Glycoconj J. 2002;19:5-11.

25. Gill RK, Mahmood S, Nagpaul JP, Mahmood A. Functional Role of Sialic Acid in IgG Binding to Microvillus Membranes in Neonatal Rat Intestine. Neonatology. 1999;76:55-64.

26. Yu Z-T, Chen C, Newburg DS. Utilization of major fucosylated and sialylated human milk oligosaccharides by isolated human gut microbes. Glycobiology. 2013;23:1281-92.

27. Van Hese I, Goossens K, Vandaele L, Opsomer G. Invited review: MicroRNAs in bovine colostrum-Focus on their origin and potential health benefits for the calf. J Dairy Sci. 2020;103:1-15.

28. Hare KS, Pletts S, Pyo J, Haines D, Guan LL, Steele M. Feeding colostrum or a 1:1 colostrum:whole milk mixture for 3 days after birth increases serum immunoglobulin $\mathrm{G}$ and apparent immunoglobulin $\mathrm{G}$ persistency in Holstein bulls. Journal of Dairy Science 2020.

29. Pyo J, Hare K, Pletts S, Inabu Y, Haines D, Sugino T, Guan LL, Steele M. Feeding colostrum or a 1:1 colostrum:milk mixture for 3 days postnatal increases small intestinal development and minimally influences plasma glucagon-like peptide-2 and serum insulin-like growth factor-1 concentrations in Holstein bull calves. J Dairy Sci. 2020;103:4236-51.

30. Conneely M, Berry DP, Murphy JP, Lorenz I, Doherty ML, Kennedy E. Effect of feeding colostrum at different volumes and subsequent number of transition milk feeds on the serum immunoglobulin $\mathrm{G}$ concentration and health status of dairy calves. J Dairy Sci. 2014;97:6991-7000.

31. Buczinski S, Vandeweerd JM. Diagnostic accuracy of refractometry for assessing bovine colostrum quality: A systematic review and meta-analysis. J Dairy Sci. 2016;99:7381-94.

32. Tyler JW, Hancock DD, Parish SM, Rea DE, Besser TE, Sanders SG, Wilson LK. Evaluation of 3 assays for failure of passive transfer in calves. J Vet Intern Med. 1996;10:304-7.

33. Windeyer MC, Leslie KE, Godden SM, Hodgins DC, Lissemore KD, LeBlanc SJ. Factors associated with morbidity, mortality, and growth of dairy heifer calves up to 3 months of age. Prev Vet Med. 2014;113:231-40.

34. Chigerwe M, Hagey JV, Aly SS. Determination of neonatal serum immunoglobulin $\mathrm{G}$ concentrations associated with mortality during the first 4 months of life in dairy heifer calves. J Dairy Res. 2015;82:400-6.

35. Urie NJ, Lombard JE, Shivley CB, Kopral CA, Adams AE, Earleywine TJ, Olson JD, Garry FB. Preweaned heifer management on US dairy operations: Part V. Factors associated with morbidity and mortality in preweaned dairy heifer calves. J Dairy Sci. 2018;101:9229-44.

36. Lombard J, Urie N, Garry F, Godden S, Quigley J, Earleywine T, McGuirk S, Moore D, Branan M, Chamorro M, et al. Consensus recommendations on calf- and herd-level passive immunity in dairy calves in the United States. J Dairy Sci. 2020;103:7611-24.

37. McGuirk SM, Collins M. Managing the production, storage, and delivery of colostrum. Veterinary Clinics of North America Food Animal Practice. 2004; 20:593-603.

38. McMartin S, Godden SM, Metzger L, Feirtag J, Bey R, Stabel J, Goyal S, Fetrow J, Wells S, Chester-Jones H. Heat treatment of bovine colostrum I: Effects of temperature on viscosity and immunoglobulin G level. J Dairy Sci. 2006:89:2110-8.

39. Kertz AF, Hill TM, Quigley JD, Heinrichs AJ, Linn JG, Drackley JK. A 100-Year Review: Calf nutrition and management. J Dairy Sci. 2017;100:10151-72.

40. Kertz AF, Prewitt LR, Everett JP Jr. An Early Weaning Calf Program: Summarization and Review. J Dairy Sci. 1979;62:1835-43.

41. Jasper J, Weary DM. Effects of ad libitum milk intake on dairy calves. J Dairy Sci. 2002;85:3054-8.

42. Khan MA, Lee HJ, Lee WS, Kim HS, Ki KS, Hur TY, Suh GH, Kang SJ, Choi YJ. Structural growth, rumen development, and metabolic and immune responses of Holstein male calves fed milk through step-down and conventional methods. J Dairy Sci. 2007;90:3376-87.

43. Drackley JK. Calf nutrition from birth to breeding. Vet Clin North Am Food Anim Pract. 2008;24:55-86.

44. Woodward TE. The optimum quantity of skim milk for calf feeding. J Dairy Sci. 1923:6:243-4

45. Marshall SP, Smith KL. Effect of different milks and levels of intake upon growth of young dairy calves. J Dairy Sci. 1970;53:1622-6.

46. Diaz MC, Van Amburgh ME, Smith JM, Kelsey JM, Hutten EL. Composition of growth of Holstein calves fed milk replacer from birth to 105-kilogram body weight. J Dairy Sci. 2001;84:830-42.

47. Flower FC, Weary DM. Effects of early separation on the dairy cow and calf: 2. Separation at 1 day and 2 weeks after birth. Appl Anim Behav Sci. 2001; 70:275-84.

48. de Passillé AM, Borderas TF, Rushen J. Weaning age of calves fed a high milk allowance by automated feeders: Effects on feed, water, and energy intake, behavioral signs of hunger, and weight gains. J Dairy Sci. 2011;94:1401-8

49. Khan MA, Lee HJ, Lee WS, Kim HS, Kim SB, Ki KS, Ha JK, Lee HG, Choi YJ. Pre- and post-weaning performance of Holstein female calves fed milk through step-down and conventional methods. J Dairy Sci. 2007a; 90:876-85.

50. Soberon F, Raffrenato E, Everett RW, Van Amburgh ME. Preweaning milk replacer intake and effects on long-term productivity of dairy calves. J Dairy Sci. 2012;95:783-93.

51. Soberon F, Van Amburgh ME: Lactation Biology Symposium: The effect of nutrient intake from milk or milk replacer of preweaned dairy calves on lactation milk yield as adults: A meta-analysis of current data. Journal of Animal Science 2013, 91:706-712. 
52. Gelsinger $\mathrm{SL}$, Heinrichs AJ, Jones CM. A meta-analysis of the effects of preweaned calf nutrition and growth on first-lactation performance. J Dairy Sci. 2016:99:6206-14.

53. Thomas TJ, Weary DM, Appleby MC. Newborn and 5-week-old calves vocalize in response to milk deprivation. Appl Anim Behav Sci. 2001;74:165-73.

54. Jensen MB, Holm L. The effect of milk flow rate and milk allowance on feeding related behaviour in dairy calves fed by computer controlled milk feeders. Appl Anim Behav Sci. 2003;82:87-100.

55. Jensen MB. Computer-Controlled Milk Feeding of Group-Housed Calves: The Effect of Milk Allowance and Weaning Type. J Dairy Sci. 2006;89:201-6.

56. Nielsen PP, Jensen MB, Lidfors L. Milk allowance and weaning method affect the use of a computer controlled milk feeder and the development of cross-sucking in dairy calves. Appl Anim Behav Sci. 2008;109:223-37.

57. De Paula Vieira A, Guesdon V, de Passillé AM, von Keyserlingk MAG, Weary DM. Behavioural indicators of hunger in dairy calves. Appl Anim Behav Sci. 2008;109(2-4):180-9

58. Rosenberger K, Costa JHC, Neave HW, von Keyserlingk MAG, Weary DM. The effect of milk allowance on behavior and weight gains in dairy calves. J Dairy Sci. 2017;100:504-12.

59. Krachun C, Rushen J, de Passillé AM. Play behaviour in dairy calves is reduced by weaning and by a low energy intake. Appl Anim Behav Sci. 2010;122:71-6.

60. Mintline EM, Stewart M, Rogers AR, Cox NR, Verkerk GA, Stookey JM Webster JR, Tucker CB. Play behavior as an indicator of animal welfare: Disbudding in dairy calves. Appl Anim Behav Sci. 2013;144:22-30.

61. Vasseur E, Borderas F, Cue RI, Lefebvre D, Pellerin D, Rushen J, Wade KM. de Passillé AM: A survey of dairy calf management practices in Canada that affect animal welfare. J Dairy Sci. 2010;93:1307-15.

62. Brunton LA, Duncan D, Coldham NG, Snow LC, Jones JR. A survey of antimicrobial usage on dairy farms and waste milk feeding practices in England and Wales. Vet Rec. 2012;171:296-6.

63. Duse A, Waller KP, Emanuelson U, Unnerstad HE, Persson Y, Bengtsson B. Farming practices in Sweden related to feeding milk and colostrum from cows treated with antimicrobials to dairy calves. Acta veterinaria Scandinavica. 2013;55:49-9.

64. Staněk S, Zink V, Doležal O, Štolc L. Survey of preweaning dairy calf-rearing practices in Czech dairy herds. J Dairy Sci. 2014;97:3973-81.

65. Klein-Jöbstl D, Arnholdt T, Sturmlechner F, Iwersen M, Drillich M. Results of an online questionnaire to survey calf management practices on dairy cattle breeding farms in Austria and to estimate differences in disease incidences depending on farm structure and management practices. Acta Vet Scand. 2015;57:44.

66. Hazards EPanel oB, Ricci A, Allende A, Bolton D, Chemaly M, Davies R, Fernández Escámez PS, Girones R, Koutsoumanis K, Lindqvist R, et al. Risk for the development of Antimicrobial Resistance (AMR) due to feeding of calves with milk containing residues of antibiotics. EFSA Journal. 2017;15:e04665.

67. Andersson DI, Hughes D. Microbiological effects of sublethal levels of antibiotics. Nat Rev Microbiol. 2014;12:465-78.

68. Langford FM, Weary DM, Fisher L. Antibiotic Resistance in Gut Bacteria from Dairy Calves: A Dose Response to the Level of Antibiotics Fed in Milk. J Dairy Sci. 2003:86:3963-6.

69. Aust V, Knappstein K, Kunz H-J, Kaspar H, Wallmann J, Kaske M. Feeding untreated and pasteurized waste milk and bulk milk to calves: effects on calf performance, health status and antibiotic resistance of faecal bacteria. Journal of Animal Physiology Animal Nutrition. 2013:97:1091-103.

70. Brunton LA, Reeves HE, Snow LC, Jones JR. A longitudinal field trial assesing the impact of feeding waste milk containing antibiotic residues on the prevalence of ESBL-producing Escherichia coli in calves. Prev Vet Med. 2014;117:403-12.

71. Pereira RW, Siler JD, Bicalho RC, Warnick LD. In Vivo Selection of Resistant E. coli after Ingestion of Milk with Added Drug Residues. PLOS ONE. 2014;9: e115223.

72. Lorenz I. Residues of Beta-lactam antibiotics in colostrum from dairy cows. 50th National Congress of the Italian Association for Buiatrics 2018, Bologna, October 10th - 13th (Poster presentation).

73. Pereira RW, Carroll LM, Lima S, Foditsch C, Siler JD, Bicalho RC, Warnick LD. Impacts of feeding preweaned calves milk containing drug residues on the functional profile of the fecal microbiota. Sci Rep. 2018;8:554.

74. Pereira RW, Lima S, Siler JD, Foditsch C, Warnick LD, Bicalho RC. Ingestion of Milk Containing Very Low Concentration of Antimicrobials: Longitudinal Effect on Fecal Microbiota Composition in Preweaned Calves. PLOS ONE. 2016;11:e0147525
75. Maynou G, Chester-Jones H, Bach A, Terré M. Feeding Pasteurized Waste Milk to Preweaned Dairy Calves Changes Fecal and Upper Respiratory Tract Microbiota. Frontiers in Veterinary Science 2019, 6.

76. Flower FC, Weary DM. The effects of early separation on the dairy cow and calf. Anim Welf. 2003:12:339-48.

77. Sumner $\mathrm{CL}$, von Keyserlingk MAG. Canadian dairy cattle veterinarian perspectives on calf welfare. J Dairy Sci. 2018;101:10303-16.

78. Ventura BA, von Keyserlingk MAG, Schuppli CA, Weary DM. Views on contentious practices in dairy farming: The case of early cow-calf separation. J Dairy Sci. 2013;96:6105-16.

79. Busch G, Weary DM, Spiller A, von Keyserlingk MAG. American and German attitudes towards cow-calf separation on dairy farms. PLOS ONE. 2017;12: e0174013.

80. Ventura BA, von Keyserlingk MAG, Wittman $H$, Weary DM. What Difference Does a Visit Make? Changes in Animal Welfare Perceptions after Interested Citizens Tour a Dairy Farm. PLOS ONE. 2016;11:e0154733.

81. Hötzel MJ, Cardoso CS, Roslindo A, von Keyserlingk MAG. Citizens' views on the practices of zero-grazing and cow-calf separation in the dairy industry: Does providing information increase acceptability? J Dairy Sci. 2017;100: 4150-60.

82. Beaver A, Meagher RK, von Keyserlingk MAG, Weary DM. Invited review: A systematic review of the effects of early separation on dairy cow and calf health. J Dairy Sci. 2019;102:5784-810.

83. Meagher RK, Beaver A, Weary DM, von Keyserlingk MAG. Invited review: A systematic review of the effects of prolonged cow-calf contact on behavior, welfare, and productivity. J Dairy Sci. 2019;102:5765-83.

84. Perttu RK, Ventura BA, Endres MI. Youth and adult public views of dairy calf housing options. J Dairy Sci. 2020;103:8507-17.

85. Hepola H. Milk feeding systems for dairy calves in groups: effects on feed intake, growth and health. Appl Anim Behav Sci. 2003;80:233-43.

86. Chua B, Coenen E, van Delen J, Weary DM. Effects of Pair Versus Individual Housing on the Behavior and Performance of Dairy Calves. J Dairy Sci. 2002; 85:360-4.

87. De Paula Vieira A, von Keyserlingk MAG, Weary DM. Effects of pair versus single housing on performance and behavior of dairy calves before and after weaning from milk. J Dairy Sci. 2010;93:3079-85.

88. Jensen MB, Larsen LE. Effects of level of social contact on dairy calf behavior and health. J Dairy Sci. 2014;97:5035-44

89. Jensen MB, Duve LR, Weary DM. Pair housing and enhanced milk allowance increase play behavior and improve performance in dairy calves. J Dairy Sci. 2015;98:2568-75.

90. Costa JHC, Meagher RK, von Keyserlingk MAG, Weary DM. Early pair housing increases solid feed intake and weight gains in dairy calves. J Dairy Sci. 2015:98:6381-6.

91. Costa JHC, von Keyserlingk MAG, Weary DM. Invited review: Effects of group housing of dairy calves on behavior, cognition, performance, and health. J Dairy Sci. 2016;99:2453-67

\section{Publisher's Note}

Springer Nature remains neutral with regard to jurisdictional claims in published maps and institutional affiliations.

Ready to submit your research? Choose BMC and benefit from:

- fast, convenient online submission

- thorough peer review by experienced researchers in your field

- rapid publication on acceptance

- support for research data, including large and complex data types

- gold Open Access which fosters wider collaboration and increased citations

- maximum visibility for your research: over $100 \mathrm{M}$ website views per year

At $\mathrm{BMC}$, research is always in progress.

Learn more biomedcentral.com/submission 